\title{
A Trinitarian approach to spirituality: Exploring the possibilities
}

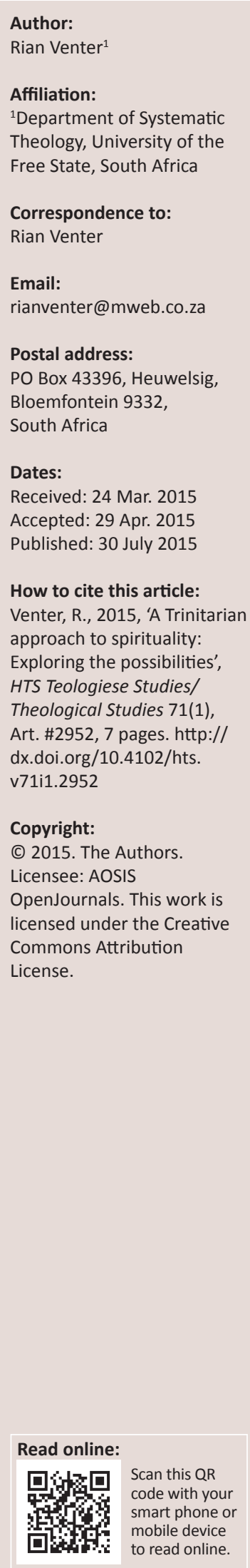

Spirituality and ultimacy are inextricably linked. Underlying the plurality of spiritualities are myriad ways to construe the identity of the transcendent. In a Christian sense, the notion of the divine with a Trinitarian identification is central. The article examines the implications of such a naming of God for spirituality. Attention is paid to the relationship between doctrinal theology and spirituality as well as to scholarly reflection already undertaken on a so-called Trinitarian spirituality. The article suggests guidelines for future work and emphasises that an adequate account should be given of how Trinitarian theology is undertaken as symbolising and hermeneutical endeavour. Some unique features of this spirituality are profiled, and it is argued that a Trinitarian imagining of the divine may generate perspectives not possible in an unqualified monotheistic approach.

\section{Introduction}

It has become fashionable to map shifts in social and intellectual life as 'turns'. The most outstanding one in the 20th century was arguably the 'turn to language' (see e.g. Rorty 1992). In this article, I am interested in two other 'turns' and in relating them intentionally to each other: the 'turn to spirituality' and the 'turn to the Trinity'. The one conveys the decline of traditional religious forms and the simultaneous increased appreciation of experience ${ }^{1}$ whereas the other conveys the new enthusiasm for the doctrine of a triune God who revealed God-self as Father, Son and Spirit. ${ }^{2}$ The research question that interests me is the potential ramification that a specific imagining of the divine could have for spirituality. Would an explicit Trinitarian understanding of the spiritual life differ from one with generic monotheistic presuppositions? Work already accomplished on such a Trinitarian approach is acknowledged, ${ }^{3}$ but a new contribution is made by examining perspectives usually not attended to; for example, the nature of the doctrinal dimension of faith and the symbolic connotations of a Trinitarian construction of divine identity. The article argues that a Trinitarian conceptualisation of spirituality does indeed result in a decisive and distinctive imprint on the spiritual life.

The article is submitted to a journal honouring the academic contribution of Prof P.G.R. de Villiers. Pieter's multidisciplinary intellectual accomplishments are impressive. His work in the field of spirituality as academic discipline in South Africa is without peer. This submission is a small expression of appreciation for Pieter's invaluable work to inform reflection on spirituality in a South-African context by the best available international scholarship.

\section{A specific question: Spirituality and the ultimate}

With the new interest in spirituality, many attempts have been made since the middle of the 20th century to conceptualise the field, and the question of a working definition became urgent. A proposal by Sandra Schneiders became particularly influential. She (Schneiders 1989:684) defines spirituality as '.. the experience of consciously striving to integrate one's life in terms not of isolation and self-absorption but of self-transcendence towards the ultimate value one perceives'. The keywords are easy to identify: experience, integration, self-transcendence and ultimate value. With this, she brilliantly captures the various sentiments of scholars of spirituality, but she also succeeds in being adequately inclusive of the multi-faced human quest for fulfilment, even in a non-religious sense. Another outstanding scholar of spirituality, Kees Waaijman (2000:6), views the object of the academic field of study of spirituality as the '... godmenselijk betrekkkingsgebeuren ... onder het oogpunt van omvorming'. It is striking that he, with an encyclopaedic approach, opts to refer immediately to a narrower category - God.

\footnotetext{
1.This is well described in the article "The "turn" to spirituality' by Kourie (2006).

2.See for a discussion, the section 'A changing horizon: Trinity in contemporary scholarship'.

3.This will be discussed in the section 'State of reflection: Contributions to a Trinitarian spirituality'.
} 
What is of interest in this article is the specification of the referent 'ultimate value' in an explicit Christian sense. Ultimacy ${ }^{4}$ is obviously understood in terms of divinity, but some additional 'naming' is required. In a Christian sense, God has a particular identity - Father, Son and Spirit. It seems to me that neither Schneiders nor Waaijman has any enthusiasm for exploring ultimacy or God - and its potential implication for spirituality - in a Christian sense. As will be noted later, Schneiders is hesitant about the role of theology in spirituality, and Waaijman (2000:425-433) has a one-sided interest in the Old Testament. In his massive work on spirituality, the references to Trinity are fairly scant. In a recent book by Perrin (2007:32), which displays in-depth acquaintance with the literature on spirituality, one encounters a good definition of Christian spirituality: 'The experience of transformation in the Divine-human relationship as modelled by Jesus Christ and inspired by the Holy Spirit.' In this description, one finds traces of both Schneiders and Waaijman as well as a critical additional element, namely the specification of ultimacy or God in terms of the Trinitarian confession. This will now be explored further.

\section{A wider context: Spirituality and theology}

With the re-thinking of spirituality as academic discipline, one question repeatedly arose in the 20th century: the relationship of spirituality to theology. One position, that spirituality is a mere expression of doctrine, was clearly unacceptable. Endean (2005:75) correctly observes that '... the contemporary study of spirituality depends on some kind of disjunction between doctrine and the spiritual'. Yet, rejecting a relationship of dependence does not amount to addressing the question. In contemporary literature, at least two approaches are mentioned: One advocates autonomy and the other a form of dialectic organic relationship (see e.g. Endean 2005:77). The name of Sandra Schneiders is usually associated with the first option. According to her (see the influential 1986 article), lived experience generates theology, not the other way round: 'Theology is a servant of Christian experience, not its master' (Schneiders 1986:271). In light of its subject area, methods and objectives, spirituality as academic discipline is independent of theology. According to Schneiders (1986:273), a 'subordinate partner' has become 'an autonomous dialogue partner'. Her argument is based on the extensive nature of experience which cannot be reduced to an expression of the doctrinal. Sheldrake (2010:71f.), another reputable scholar of spirituality, argues for a more dialogical approach, that is, there should be a form of reciprocal evaluation. For spirituality to be considered 'Christian', there has to be some relationship to classic Christian doctrine, for example the Trinity, the incarnation and eschatology. On

4.The term "ultimacy' is used with an intentional open and inclusive connotation The study of spirituality has emphasised that the most important reality which generates meaning and integration to people need not be religious at all; it should not be understood in a narrow theistic sense of a personal God. Even in the study of comparative religion, one encounters the assumption that not all religions ar premised on the basis of a personal divinity. 'Ultimacy' is a broad and inclusive term which refers to what is understood in variegated ways as the final reality that generates orientation to people and to communities and that has as such a certain indeterminacy. Strictly speaking, it is a wider category than divinity or God. For good discussion, see the recent work by Neville (2013). the other hand, spirituality should remind theology that it is self-implicating and performative: 'To do theology means becoming a theological person' (Sheldrake 2010:72).

That spirituality cannot be inferred deductively from a number of doctrinal propositions is a significant advance in more recent reflection. The role played by doctrinal perspectives requires more nuanced explanation. The precise nature of the doctrinal element of the Christian faith should be examined. The influential work by George Lindbeck (1984) and his cultural-linguistic approach to religion and regulative view of doctrine could be employed productively in the conversation on spirituality and theology. He emphasises that religions are comprehensive interpretive schemes which 'structure human experience' (Lindbeck 1984:32): 'There are numberless thoughts we cannot think, sentiments we cannot have, and realities we cannot perceive unless we learn to use the appropriate symbol systems' (Lindbeck 1984:34). Doctrinal symbols (for example, the notion of the divine as triune) creates a hermeneutical space which structures, interprets and even produces religious experience. If Lindbeck's understanding of doctrine is tenable, theology as cognitive linguistic interpretation of reality becomes indispensable for spirituality. Different doctrinal 'worlds' are constructed by different religions which becomes generative of experience. If these worlds do have a narrative character, as is the case with the Christian faith, the performative impact is even stronger. Stories form a specific narrative self. ${ }^{5}$ A distinctive Christian spiritual experience results from an encounter and eventual integration of the narrative of a God with a unique history.

The pejorative labels usually and dismissively attached to 'doctrine' should not be accepted too readily. In a Gestalt sense, doctrinal expression creates a symbolic world for Christian living. Charry (1997a) convincingly argues that doctrine has a 'sapiential' aim. Its primary task is not to convey correct information but to function 'salutarily', that is, it engages believers that '... life with the triune God facilitates dignity and excellence' (Charry 1997a:18). Doctrines do not challenge people to simply consent to propositions but guide them to form identity and character. As doctrines are hermeneutical constructs that present interpretations of, for example, origin, salvation and destiny, they should be regarded as formative. Major thinkers of hermeneutics, such as Gadamer, Ricoeur and Betti, all stressed that understanding is more than acquiring information. Rather, it involves formation (see the excellent discussion in Thiselton 2007:81-97). Theology does matter for spirituality.

\section{A changing horizon: Trinity in contemporary scholarship}

During the intense debate and controversies of the 4th century, the specific and unique Christian understanding of God crystallised and was conceptually stabilised. It is important to note that the originating impetus behind this

5.For a good orientation on the formative impact of narrative, see the essays in Hauerwas and Jones (1989) 
long development was an experience by people who were monotheists. Ultimately, the Trinitarian doctrine was an attempt to make sense, cognitively and linguistically, of a salvific experience of Jesus as resurrected and of the Spirit as transforming power. After the creedal stabilisation, the doctrine became the touchstone of orthodoxy. Although always liturgically central, historians of the Trinitarian theology are divided as to how to map the subsequent history: Has the confession been marginalised theologically and spiritually? A majority of these historians are of the opinion that Christians are mere 'monotheists' or 'practical modalists'.

A drastic change that took place during the 20th century is often referred to as a 'Trinitarian Renaissance' or a 'rediscovery of the Trinity', and the two Karls, Barth and Rahner, are usually credited with this new direction although the roots may be traced much further back to German Idealism. The systematic theological horizon is flooded with literature, and there are still no signs of it abating. For excellent overviews of the many aspects of this discourse, see Emery and Levering (2011) and Phan (2011).

It is obvious that the numerous and intriguing facets cannot be discussed in this article. However, excellent overviews are available (see e.g. Kärkkäinen 2009; Schwöbel 2014). I can only allude to some pertinent insights. The Trinitarian confession of one God differentiated in three Persons is the Christian identification of the divine. The 'face' that God revealed in the history of the economy of salvation is how God is eternally in God-self. With the renewal of Trinitarian theology, personhood and relationality emerged strongly as the primary categories of God-talk, replacing a substance ontology (Kärkkäinen 2009:12). With the new appreciation of the Cappadocian legacy contra the dominant Augustinian tradition, 'social trinities' were articulated especially by theologians such as Boff, Moltmann, Gunton and a host of others. To rethink traditional doctrines in Trinitarian light, for example anthropology and ecclesiology, has become a theological imperative. However, an exciting additional challenge also materialised: to re-envision typical conundrums - faith and science, faith and society, and faith and experience. LaCugna's (1991:ix) programmatic statement that the Trinity '... is an eminently practical doctrine with far-reaching consequences for Christian life' was embraced with much rigour. The present article should also be placed in this context. In no way should this Trinitarian enthusiasm be portrayed as a unanimous venture amongst theologians. In fact, some are claiming that it drastically deviates from the Patristric intention (see, for example, the debate in Sexton \& Gundry 2014). However, Kärkkäinen's (2009:21) conviction is worth quoting: 'Far from being an archaic doctrine, Trinity has proven itself to be source of vital debate and spiritual renewal.'

\section{State of reflection: Contributions to a Trinitarian spirituality}

All Christian spirituality is inherently Trinitarian spirituality: The relationship with God was initiated by the Father through the work of Jesus Christ, and it becomes effective in the Spirit. The Christian liturgy has always maintained a consistent Trinitarian character - from the greeting to the Trinitarian benediction. The question relates to the extent to which the specifics, the dynamics and the possibilities of the first-order experience of this God have been intentionally explored in second-order theological reflection. That is the focus of this article. One should immediately acknowledge the work already done by other scholars. In this section, I shall briefly summarise four endeavours, each of which conveys important insights that have to be incorporated in a systematic treatment. ${ }^{6}$

Gresham (2000) draws attention to a variety of Trinitarian spiritualities. This basic fact begs careful consideration: There is no single unanimous Trinitarian theology in the church and in theology. Firstly, Gresham (2000:284ff.) discusses the '... contemplative spirituality of the divine Trinitarian indwelling in the soul'. This is the typical AugustinianThomistic approach based on a psychological analogy of the Trinity in the soul - remembering, knowing and loving (willing). The deeper the believer moves inward through silence, emptiness and contemplation, the more the Son and the Spirit are encountered in knowledge and love. The usual critique directed against this spirituality is its restrictive nature: It is individualistic and furthers self-occupation. The second approach mentioned by Gresham (2000:286ff.) is called the '... social spirituality of participation in the Trinitarian fellowship'. The intellectual impetus behind this is the work by the Cappadocian Fathers, and the analogies are rather of a social nature, that is, found in persons in relationship. The critical difference with the first approach is that the Trinity does not dwell in the human soul, but the human 'participates' in the divine fellowship of the Father, Son and Spirit on the basis of the filiation of believers through the work of Christ. God is not experienced through an inward turn but through an outward movement to various relationships. The conventional weakness of this approach is its alleged inability to overcome tritheism. Gresham's (2000:288) comment is worth mentioning: 'Yet, this approach to Trinitarian theology and spirituality offers such a rich understanding of divine life and our sharing in that life that the risk of tritheism is worth taking.' The third possibility identified by Gresham (2000:289) is a typical Eastern Orthodox approach called the '... sacramental spirituality of Trinitarian missions'. It is based on the distinction between baptism and confirmation, and its dual foci are on the missions of Christ and the Spirit and the eventual double movement towards God and towards the world. The questionable element in this spirituality is the untenable divorce between Christ and the Spirit and the consequent non-integrative movement of the believers. The value of Gresham's work is the critical reminder that a Trinitarian spirituality could be constructed in variegated ways. A great deal will depend on where the focus is placed and what element of the complex traditional Trinitarian configuration is highlighted.

6.For more discussions, see also Dupré (1984) and Mclntosh (2005). 
LaCugna and Downey's (1993) article on Trinitarian spirituality warrants careful study. Not only are they specialists in the fields of Trinitarian theology and spirituality, respectively, but their article also captures the critical elements in the discourse on Trinity and spirituality. The turn to relationality informs the conceptualisation of God and consequently has ramifications for constituent elements of spirituality. They explicitly mention that a Trinitarian spirituality '... made it possible to see the whole Christian life quite differently' (LaCugna \& Downey 1993:969). Several fundamental insights govern their vision. Departing from a socially informed Trinitarian theology, which takes the revelation of God as three distinct Persons seriously, they (LaCugna \& Downey 1993:970, 973) consider personhood as the ultimate ontological category. Not only is God relational, but 'relationship' and 'communion' become primary motifs in this spirituality. They also reject the separation of the divine into two parts - ad intra and ad extra - that is, a God who first lives for God-self and then enters into some relationship with creation. They consider the splitting of God into an immanent and an economic dimension as the cause of unacceptable dichotomies in Christian life (for example, between the sacred and the profane). There is ' ... one God who is precisely God for us' (LaCugna \& Downey 1993:974). In light of this reconstruction of their understanding of the divine in a Christian sense, they subsequently revisit traditional notions in spirituality. Holiness is not an inward journey, typical of the Augustine tradition; it is a journey of 'self-donation', a '... journey to ever more complete communion between persons both divine and human' (LaCugna \& Downey 1993:973). A Trinitarian spirituality is especially critical of a spirituality that, in essence, is simply self-occupation and narcissism (LaCugna \& Downey 1993:970, 972). As the triune God is 'the paradigm of human relationships' and 'human personhood iconic of divine personhood' (LaCugna \& Downey 1993:973, 980), relationality is the central optic in this approach to spirituality. It requires attention to the myriad relationships in which the human being exists. It is critical of relationships of submission, powerlessness and passivity. As '... union with God is to be found in every form of communion' (LaCugna \& Downey 1993:975), justice acquires special attention in Trinitarian spirituality. It values rightly ordered relationships, relationships of respect and reciprocity. Lacugna and Downey's work ${ }^{7}$ is important, and further reflection should take note of their insights, especially their emphasis on relationality, communion, participation in both the life of God and with others, holiness as outward journey of donation and social justice as central to the union with God. That an intentional re-envisioning of the divine could have drastic implications for spirituality emerges without doubt in their scholarly work.

The contribution by the British systematic theologian Sarah Coakley, who held a chair at Harvard and now at Cambridge, is not only fascinating but exceedingly important. Her théologie totale evidences an impressive command of several

7.In his book on Trinitarian spirituality, Downey (2000:48) gives primacy to the notion of gift - 'The doctrine of the Trinity is a grammar of gift'. disciplines, and her vision is singularly comprehensive. In her recent systematic theology God, sexuality and the self (2013), she combines contemporary Trinitarian theology, Patristic Studies, spirituality, gender theory and aesthetics. Her richly textured theology cannot be adequately summarised in this instance, and I can allude to only some of her concerns. She tries to counter attempts by British scholars, in particular, to erode Trinitarian theology by claiming that the doctrine cannot be experienced. Her approach to the Trinity, starting with the Spirit and with prayer (see, for example, her 1986 article), is a rebuttal of this critique which had already been voiced by Schleiermacher. The critical question, according to her, is 'Why three?', 'Why was the doctrine needed at all?' (Coakley 2013:100). With an appeal to Romans 8 (especially vv. 14-17a and 26-27), she argues that the Spirit is doing the praying in the believer, that the Father receives and that the Son invites into divine sonship. The experience is ultimately unitary but with a triadic structure: The Spirit is the 'enabler', the Father the 'source and object', and the Son the 'perfected creation' (Coakley 1998:226, 2013:114). According to Coakley (2013:113), prayer ' $\ldots$ is the only valid experientially based pressure towards hypostatizing the Spirit'. In an intriguing reading of the Patristic sources on Trinity, prayer and sexuality, she asserts that a 'Spirit-leading approach to the Trinity' (Coakley 2013:102) was a known option but eventually dismissed because of its inherent dangers (for example, the loss of sexual control). Coakley's own project is a retrieval and contemporary development of this tradition. Central in her creative theological construct is the category of desire and the quest to delineate an 'ontology of desire' (Coakley 2013:6, 92). The reality of 'unredeemed desire' lurks at the basis of problems of knowledge, power and relationship (Coakley 2013:52), and sin is also 'misdirected desire' (Coakley 2013:59). She aims to address this with a Trinitarian theology of desire. Desire is primarily a manifestation of divine ekstasis. Human relationships, including gender and sexual relationships, are derived from this. Many contemporary dilemmas could be addressed with a Trinitarian 'right ordering of desire' (Coakley 2013:2), especially through contemplative practices. This is not only a progressive incorporation into the life of God but also '... an intensification of attention to the "other"' (Coakley 2013:87). This simplified presentation of Coakley's theology highlights the close interaction between Trinitarian theology, prayer and social relational challenges. Trinity, contemplation and politics are inextricably linked in her vision.

The unfortunate divide between mystical consciousness and doctrinal theology caused theology to pay scant attention to the insights offered by mystics. Anne Hunt (2010) rendered a valuable service with her study of the Trinitarian insights of eight prominent mystics. ${ }^{8}$ One can obviously not describe the experiences of saints such as William of St Thierry, Hildegard of Bingen, Julian of Norwich and John of the Cross in this article, but it is worth taking note of Hunt's conclusions to her marvellous study (Hunt 2010:182-187). She emphasises

8.Research by the South African scholar Celia Kourie on mysticism and Trinity should be acknowledged. For one example of her scholarly contribution, see the study on Jan van Ruusbroec (Kourie 2008). 
that their educational backgrounds clearly influenced the articulation of their experiences, which were also thoroughly orthodox. The mystery of the Trinity is viewed as the basic datum of faith, and all shared a sense of the sheer donum thereof. Central in their experiences is the entry into the union with God, which they communicated in a variety of images as '... an entry into the Trinitarian relations' (Hunt 2010:184). This movement into the Trinitarian mystery simultaneously effected a profound transformation. The mystics differed as to how the entry takes place; some stress the work of the Spirit, others that of the Son. Hunt's (2010) final conclusion is worth quoting in full:

What they would all have us understand, above all else, is the Trinity as mystery of love, the innertrinitarian love of the Three for each other, and their distinctive threefold love for us and for all creation. (p. 185)

The state of scholarship remains a well of wisdom from which one should drink. The selection of theological works on spirituality attentive to Trinitarian resources has revealed important perspectives that should be incorporated in further investigation. A Trinitarian imagination always meets us in plural form. From the earliest Christian era, thinkers emphasised different aspects of the confessional matrix. The more recent preference for a relational approach opens avenues that should be carefully investigated. The attempts to overcome alienation between contemplation and social commitment are constructive and signal a direction that can hardly be ignored. The work on mysticism as unmediated experience should be pursued, but the finding that even that unique experience is not without some interpretative grid underlines the inescapable task of articulating a conceptual account of the divine.

\section{The way forward: Thinking spirituality Trinitarianly}

Construing spirituality with a Trinitarian sensibility is in a sense inevitable, considering the central place of the confession in the Christian faith. With the recent interest in and appreciation of doctrine and significant contributions towards such research, the challenge becomes all the more acute. In this concluding section, some guidelines are suggested which may map the direction of future reflection:

1. The Trinitarian doctrine resists simplistic and reductionist thinking, considering the very mystery of the divine it expresses. A Trinitarian identification of ultimacy immeasurably complicates human speaking of the divine, in a sense more than an unqualified monotheism. A new set of intellectual conundrums such as unity amidst diversity, simplicity versus complexity and immutability versus change come into play. A conscious epistemic modesty should accompany all reflection in this regard, also as far as such a spirituality is concerned.

2. At the same time, a strange paradox should be mentioned. Trinitarian theologising displayed from the very beginning a kataphatic character. The complexity of the divine never deterred Patristic theologians from speaking, from naming. The Mystery compelled and stimulated intellectual articulation. The rigorous attempts of the early fathers to find adequate categories to express the unity and distinctiveness of the divine life remain impressive. The love for this God and the love of learning were never in conflict. ${ }^{9}$ Contemporary debates (for example, on the viability of a social model) manifest a similar propensity towards strenuous intellectual engagement. The implications for a spirituality informed by this tradition should not be missed.

3. As was intimated earlier in this article, a Trinitarian spirituality could never be homogeneous. Trinitarian theology has, from the beginning, been pluralistic. Whether the conventional distinction between East and West is currently still tenable is open for debate, ${ }^{10}$ but the fact remains that different constructions are possible. For example, the basic point of departure - the one nature or the three persons - results in divergent profiles. Trinitarian doctrine has been mediated by the large confessional traditions and has resulted in spiritualities with unique features due to a vast number of ecological factors. At present, confessional spiritualities with an explicit Trinitarian frame may lead to greater convergence than was historically possible. Increasingly, Western-oriented theologies develop an appreciation for the Cappadocian achievement, which narrows the conceptual divide.

4. After these introductory comments, which address formal matters, an attempt can be made to specify the material features of this spirituality. However, I should briefly explain the nature of doing Trinitarian theology. What is attempted in this article is obviously one specific endeavour of applied Trinitarian theology. Rarely do scholars give an explicit account of how they are doing Trinitarian theology. Only some comments can be offered in this instance. Two levels of signification take place: Symbols are formed, and connotations are created. This God, with a unique identify, has a specific history - a history encompassing Ancient Israel and the man Jesus of Galilee. Certain events take place in this particular history, or to put it differently, divine agency is manifested. The creation of the cosmos, the liberation from Egypt, the return from exile and the birth, death and resurrection of Jesus take place, and an expectation is created of a cosmic completion and the establishing of a 'new earth'. These 'events' become religious symbols that require interpretation. For example, the liberation from Egypt, the return from exile, the resurrection of Jesus and the expectation of a cosmic destiny signify future and hope. The triune God is identified with these symbols and, eventually, with the interpretative associations. However, and this is critical, each divine Person is associated with some of these symbols in an intensified manner, for example, Jesus with the cross.

9.See the work on monastic culture by LeClercq (1982) with the striking title The love of learning and the desire for God.

10. In a recent comprehensive study, Webb (2014) maintains the distinctive theologies of East and West and locates the crux in different approaches to the relationship between symbol and experience, the one more mystical and the other more speculative. 
A detailed and consistent theology will display an antenna for these symbols and connotations with an emphatic association. Precisely in this instance does one find the distinction from a mere monotheistic theology. Trinitarian divine agency acquires an exceptional scope, diversity and richness in this hermeneutical and hypostatic appropriation. Doing Trinitarian theology is inherently a hermeneutical, creative and imaginative project. The identity of a specific divinity is construed in terms of a biblical narrative. The events become tensive symbols, thus constituting a surplus of meaning that must be continually explored.

5. As a result of this brief explanation, two perspectives are crucial for the development of a spirituality in a Trinitarian key. The symbols are not disconnected or fragmentary but configure jointly to form a Trinitarian narrative world inhabited by those who believe in this world. People who have been baptised in the strong name of Father, Son and Spirit become citizens of this symbolic universe which orders their experience and their spirituality. This world is a world interpreted; each symbol carries with it hermeneutical associations and connotations. This renders a Trinitarian spirituality recognisable, despite its confessional pluralistic character. These interpretative 'labels' form the recognisability, the distinctiveness. The contours of this Trinitarian world should be mapped more clearly. Obviously, not a singular map can be drawn in this instance.

6. Minimally, at least six features should be distinguished: integration, grace, kenosis, hope, relationality and beauty. Each of these terms or notions carries a range of semantic possibilities as will be explained. The God who created is also the God who initiated salvation. The Trinitarian economy is a story of a God who saves, who sent his Son and who realised this through his Spirit. This unity of creation and salvation resists a spirituality which is tempted to divide life in dichotomies. It is a spirituality of the earth, of the body and of the depths of the human spirit. It is an integrated spirituality. This narrative of salvation is a story of grace, of a God who gives God-self, who welcomes the sinner, who demands no reciprocal performance. The experience of this God is marked by the joy of liberative hospitality. The central symbol of the cross gives meaning to self-emptying, to self-donation, to vulnerability as the way to life and fulfilment. It creates a spirituality which finds the divine in abandonment, in silence and in darkness. The future generating God - the God of the exodus, of the exile, of the resurrection, of the return - makes feasible the possibility of a historical novum, especially through the Spirit. A spirituality of vulnerability is also a spirituality of hope. The dialectic of cross and resurrection critiques defeatism and triumphalism. The relational God is a God of love, of justice. A Trinitarian spirituality discerns the presence of the triune God in the 'face of the other'. As the New Jerusalem will be 'filled with the glory of God', beauty will be the final word in a world marked by a myriad traces of ugliness. The victory of the glory of God has already stimulated a desire for beauty in this life. ${ }^{11}$ These few and cursory comments give an indication of what kind of spirituality germinates in the fertile soil of a Trinitarian land.

7. It is possible and even desirable to reinterpret holiness Trinitarianly. Trinitarian holiness will be informed by these associations to give it a remarkably unique character, unlike so many moralistic versions. ${ }^{12}$ Holiness engages this world in all its materiality; it is generous, ecstatic and self-negating. Holiness values the embrace of alterity ${ }^{13}$ and seeks the possibility of newness amidst despair. It turns away from that which denigrates nature, which is self-serving and cynical. Those who accept this journey turn to the world, to the other, and discern the presence of the divine in the weak and powerless. ${ }^{14}$ McIntosh's study on Trinitarian spirituality intersects with this. He identifies three marks of such a spirituality: 'selftranscendence, a deepening love for others, a growing sense of freedom and agency' (McIntosh 2005:179).

8. As the human is iconic of the divine, faith in this God who is triune transforms the person in a distinct self. And this is the heart of the matter, of the attempt to think spirituality in Trinitarian terms. The Trinitarian self is at once complex, integrated and tendentious. It is dynamic and directional self, a self in the process of growing towards the physical world, towards conditions of justice, away from itself. It is an aesthetic, utopian and ever-expanding self. Charry, (1997b:379) who argued impressively for the formative function of the Trinitarian doctrine, puts this strikingly: '[T] a coherent, morally reasonable, unified, and godly that is to say, happy life'.

9. A Trinitarian spirituality encourages a boundless spectrum of practices. As it is a spirituality empowered by the Spirit of the Father and the Son, it encompasses the range of human praxial possibilities. The Spirit is the spirit of life, of justice, of beauty as seen in the Old Testament, and it is the spirit of unity, of charismata and of the future as witnessed in the New Testament. A Trinitarian spirituality encounters the presence of this God in the liturgy, in contemplation, in social action and in aesthetic experimentation. It is fundamentally a creative and emergent spirituality.

10. The distinctiveness of a Trinitarian spirituality cannot be reduced to a single denominator. Its recognisability is to be found in the configuration of the variety of

11.The neglect of the aesthetic dimension of faith has been redressed by the intellectual endeavours of the great scholar Hans Urs von Balthasar, and increasingly, beauty is highlighted in theology. See, for example, the work on pneumatology and beauty by Sherry (2002).

12.For a discussion of holiness in terms of the Trinity, see Webster (2003). He explicitly stresses the relational character of holiness (Webster 2003:45).

13.In a general sense, 'alterity' refers to 'otherness'. In ethical and post-colonial theory (e.g. Levinas \& Spivak), it has acquired a more nuanced definition. In this article, 'alterity' is used to denote social realities like race, gender and class. However, more is at stake. It could refer to practices and attitudes that differ from convention as 'normal' or 'true'; for example, faith or sexual orientation. In a sense, 'alterity' is a 'normal' or 'true'; for example, faith or sexual orientation. In a sense, 'alterity' is a
resistance category to destabilise deeply ingrained norms, practices and concepts of truth. See Ashcroft, Griffiths and Tiffin (2013:12f.) for a discussion.

14.Power and Downey (2012) develop the theme of the triune God and justice in their work. They create the apt formulation 'naming of God as an ethical project' (see Chapter 3 of their work). 
dimensions formed by the shape of the mental world which the believer inhabits. As the relationship with the triune God is intersubjective, the 'symbolic world' has not been completed. It is dynamic and in the process of hermeneutically becoming. It is a world open to new discoveries and surprises, but the elements of this world are stable: The grace, the love, the justice cannot disappear or change their properties.

\section{Conclusion}

In conclusion, one could justifiably state that attention to the specific naming of ultimacy in a religious tradition could be a fruitful endeavour. A Trinitarian grammar allows for an intricate but beautiful spiritual language.

\section{Acknowledgements Competing interests}

The author declares that he has no financial or personal relationships which may have inappropriately influenced him in writing this article.

\section{References}

Ashcroft, B., Griffiths, G. \& Tiffin, H. (eds.), 2013, Post-colonial studies: The key concepts, Routledge, New York, NY.

Charry, E.T., 1997a, By the renewing of your minds: The pastoral function of Christian doctrine, Oxford University Press, Oxford.

Charry, E.T., 1997b, 'Spiritual formation by the doctrine of the Trinity', Theology Today 54, 367-380. http://dx.doi.org/10.1177/004057369705400307

Coakley, S., 1998, 'Living into the mystery of the Holy Trinity: Trinity, prayer, and sexuality', Anglican Theological Review 80, 223-232.

Coakley, S., 2013, God, sexuality, and the self: An essay 'On the Trinity', Cambridge University Press, Cambridge. http://dx.doi.org/10.1017/cbo9781139048958

Downey, M., 2000, Altogether gift: A Trinitarian spirituality, Orbis, Maryknoll, NY

Dupré, L., 1984, 'From silence to speech: Negative theology and Trinitarian spirituality', Communio 11, 28-34.

Emery, G. \& Levering, M. (eds.), 2011, The Oxford handbook to the Trinity, Oxford University Press, Oxford. http://dx.doi.org/10.1093/oxfordhb/9780199557813. 001.0001

Endean, P., 2005, 'Spirituality and theology', in P. Sheldrake (ed.), The new Westminster dictionary of Christian spirituality, pp. 74-79, Westminster John Knox, Louisville, KY.
Gresham, J.L., 2000, 'Three Trinitarian spiritualities', in K.J. Collins (ed.), Exploring Christian spirituality: An ecumenical reader, pp. 283-295, Baker, Grand Rapids, MI.
Reristian

Hauerwas, S. \& Jones, L.G. (eds.), 1989, Why narrative? Readings in narrative theology, Eerdmans, Grand Rapids, MI.

Hunt, A., 2010, The Trinity: Insights from the mystics, Liturgical Press, Collegeville, MN.

Kärkkäinen, V.-M., 2009, 'The trajectories of the contemporary "Trinitarian Renaissance" in different contexts', Journal of Reformed Theology 3, 7-21. http:// dx.doi.org/10.1163/156973109X403697

Kourie, C., 2006, 'The 'turn' to spirituality', Acta Theologica Supplementum 8, 19-38.

Kourie, C., 2008, 'The Trinitarian mysticism of Jan van Ruusbroec (1293-1381)', Studies in Spirituality 18, 133-148. http://dx.doi.org/10.2143/SIS.18.0.2033286

LaCugna, C.M., 1991, God for us: The Trinity and Christian life, HarperCollins, New York, NY.

LaCugna, C.M. \& Downey, M., 1993, 'Trinitarian spirituality', in M. Downey (ed.), 1993, The new dictionary of Catholic spirituality, pp. 968-982, Liturgical Press, Collegeville, MN

LeClercq, J., 1982, The love of learning and the desire for God, Fordham University Press, New York, NY.

Lindbeck, G.A., 1984, The nature of doctrine: Religion and theology in a postliberal age, Westminster, Philadelphia, PA.

McIntosh, M.A., 2005, 'Trinitarian perspectives on Christian spirituality', in A. Holder (ed.), The Blackwell companion to Christian spirituality, pp. 177-189, Blackwell, Oxford. http://dx.doi.org/10.1002/9780470996713.ch11

Neville, R.C., 2013, Ultimates: Philosophical theology, vol. 1, SUNY, Albany, NY.

Perrin, D.B., 2007, Studying Christian spirituality, Routledge, London.

Phan, P.C. (ed.), 2011, The Cambridge companion to the Trinity, Cambridge University Press, Cambridge. http://dx.doi.org/10.1017/CCOL9780521877398

Power, D.N. \& Downey, M., 2012, Living the justice of the triune God, Liturgical Press, Collegeville, MN.

Rorty, R.M. (ed.), 1992, The linguistic turn: Essays in philosophical method, University of Chicago Press, Chicago, IL.

Schneiders, S.M., 1986, 'Theology and spirituality: Strangers, rivals, or partners?', Horizons 13(2), 253-274.

Schneiders, S.M., 1989, 'Spirituality in the academy', Theological Studies 50, 676-697. http://dx.doi.org/10.1177/004056398905000403

Schwöbel, C., 2014, 'Where do we stand in Trinitarian theology?: Resources, revisions, and reappraisals', in C. Chalamet \& M. Vial (eds.), Recent developments in Trinitarian theology: An international symposium, pp. 9-71, Fortress, Minneapolis, MN.

Sexton, J.S. \& Gundry, S.N. (eds.), 2014, Two views on the doctrine of the Trinity, Zondervan, Grand Rapids, MI.

Sheldrake, P.F., 2010, Explorations in spirituality: History, theology, and social practice, Paulist, New York, NY.

Sherry, P., 2002, Spirit and beauty, 2nd edn., SCM, London.

Thiselton, A.C., 2007, The hermeneutics of doctrine, Eerdmans, Grand Rapids, MI.

Waaijman, K., 2000, Spiritualiteit: Vormen, grondslagen, methoden, Kok, Kampen.

Webb, S., 2014, In search of the triune God: The Christian paths of east and west, University of Missouri Press, Columbia, MO.

Webster, J., 2003, Holiness, Eerdmans, Grand Rapids, MI. 